\title{
SEMAKIN BERAGAM SEMAKIN BAIK? \\ ISU KEBERAGAMAN GENDER, KEUANGAN, DAN INVESTASI PERUSAHAAN
}

\author{
Zhafarina Isti Ramadhani \\ Desi Adhariani \\ Departemen Akuntansi Fakultas Ekonomi dan Bisnis Universitas Indonesia \\ Kampus UI Depok, 16424, Indonesia
}

\begin{tabular}{ll}
\hline & Abstract \\
\cline { 2 - 2 } $\begin{array}{l}\text { Keywords: } \\
\text { Financial Perfor- }\end{array}$ & $\begin{array}{l}\text { This research aimed at investigating the impact of gender diversity on financial performance and } \\
\text { investment efficiency in public companies listed in Indonesia Stock Exchange. As there was an } \\
\text { Diversity, Invest- }\end{array}$ \\
ment Efficiency & $\begin{array}{l}\text { including Indonesia, it was important to know whether there was an influence to evaluate the role } \\
\text { of gender diversity. The sample consisted of } 282 \text { and } 253 \text { public companies listed in Indonesia }\end{array}$ \\
JEL Classification: & $\begin{array}{l}\text { Stock Exchange in } 2012 \text { (for two different models). Using secondary data and regression tests to } \\
\text { analyze the data, this study did not find the significant impact of gender diversity on financial } \\
\text { performance and investment efficiency. This could be interpreted as there were still many things to } \\
\text { do to improve the role of gender diversity and women capabilities in board of commissioners and } \\
\text { directors. }\end{array}$
\end{tabular}

\begin{abstract}
Abstrak
Penelitian ini bertujuan untuk menguji pengaruh keberagaman gender pada dewan komisaris dan dewan direksi terhadap kinerja keuangan perusahaan dan efisiensi investasi pada perusahaan-perusahaan publik di Indonesia. Menimbang adanya kenaikan jumlah wanita yang menempati posisi di dewan direksi dan komisaris maka penting untuk mengetahui pengaruhnya guna mengevaluasi peran keberagaman gender. Metode pengujian menggunakan regresi linear berganda dengan data sampel sejumlah 282 dan 253 perusahaan yang terdaftar di Bursa Efek Indonesia pada tahun 2012 (untuk dua model yang berbeda). Hasil penelitian menunjukkan bahwa keberagaman gender pada dewan komisaris dan dewan direksi tidak berpengaruh signifikan, baik terhadap kinerja keuangan perusahaan maupun terhadap efisiensi investasi perusahaan. Hal ini mengimplikasikan bahwa masih banyak yang perlu dilakukan untuk meningkatkan peran keberagaman gender dan kapasitas wanita di dewan direksi dan komisaris.
\end{abstract}

Kata kunci:

Kinerja Keuangan,

Keberagaman

Gender, Efisiensi

Investasi 


\section{Jurnal Keuangan dan Perbankan | KEUANGAN}

Vol. 21, No.1, Januari 2017: 1- 13

Sejak terjadinya krisis moneter yang terjadi di negara-negara Asia pada akhir tahun 1990-an, muncul ide untuk meningkatkan kerangka tata kelola perusahaan di tingkat nasional maupun regional. Studi yang dilakukan oleh Asian Development Bank (ADB) mengidentifikasi bahwa kontributor utama dari krisis ekonomi tersebut yakni lemahnya tata kelola perusahaan (Zhuang, et al., 2000). Hal tersebut mendorong negara-negara di Asia untuk meningkatkan performa tata kelola perusahaan, tak terkecuali di Indonesia.

Berdasarkan Roadmap Tata Kelola Perusahaan Indonesia yang diterbitkan oleh Otoritas Jasa Keuangan (OJK) pada tahun awal tahun 2014, tata kelola perusahaan yang baik memerlukan kerangka tata kelola perusahaan, perlindungan terhadap pemegang saham, peran pemangku kepentingan, transparansi informasi, serta peran dan tanggungjawab dewan komisaris dan dewan direksi.

Kim et al. (2009) berpendapat bahwa dalam teori tata kelola perusahaan, struktur dewan memiliki pengaruh yang kuat pada tindakan yang dilakukan dewan dan manajemen puncak yang pada akhirnya dapat memengaruhi kinerja perusahaan. Selain itu, pada era globalisasi saat ini, para investor juga mulai menuntut peran dan tanggung jawab dewan komisaris dan dewan direksi untuk memenuhi harapan mereka. Salah satunya melalui komposisi dewan komisaris dan dewan direksi yang beragam. Keberagaman (diversity) pada dewan komisaris dan dewan direksi diharapkan dapat mendorong pengambilan keputusan yang objektif dan komprehensif karena keputusan dapat diambil dari berbagai macam sudut pandang.

Keberagaman komposisi dewan komisaris dan dewan direksi dapat diklasifikasikan dari segi usia, etnis, dan jenis kelamin. Selain itu juga terdapat keberagaman dalam hal kepemilikan, pengalaman, latar belakang pendidikan, dan status sosial ekonomi (Jackson \& Alvarez, 1992; Sessa \& Jackson, 1995). Dengan mengidentifikasi keberagaman dari kelompok minoritas, baik perempuan maupun etnis minoritas, maka dapat menguji apakah dengan ada atau tidak adanya kelompok minoritas tesebut dapat memengaruhi performa perusahaan, baik dari segi tata kelola perusahaan, tanggung jawab sosial perusahaan, inovasi, serta strategi perusahaan. Hal ini mengacu pada hasil penelitian sebelumnya yang telah melakukan upayaupaya untuk menghubungkan keberagaman dengan aspek yang berbeda dalam perusahaan, seperti perubahan strategi perusahaan (Wiersema \& Bantel, 1992; Goodstein et al, 1994), inovasi organisasi (Bantel \& Jackson, 1989), tata kelola perusahaan (Adams \& Ferreira, 2009), dan tanggung jawab sosial perusahaan (Coffey \& Wang, 1998).

Berdasarkan penelitian sebelumnya, mulai terjadi peningkatan jumlah perempuan pada dewan komisaris dan direksi di berbagai negara. Rose (2007) melaporkan bahwa terdapat keinginan untuk meningkatkan peran perempuan pada anggota dewan secara signifikan. Norwegia telah memiliki hukum yang mengharuskan $40 \%$ dari anggota dewan adalah perempuan (Rose, 2007), sedangkan Spanyol juga mengeluarkan undangundang terkait kuota untuk jumlah anggota dewan perempuan (Adams \& Ferreira, 2009).

Di Indonesia, berdasarkan hasil studi Centre for Governance, Institutions and Organisations (2012), persentase perempuan pada dewan komisaris dan dewan direksi perusahaan publik yang terdaftar di Indonesia Stock Exchange (IDX) adalah sebesar $11,6 \%$. Dari nilai tersebut, sebesar 34\% dewan perusahaan hanya memiliki satu wanita pada anggota dewan dan hanya 2,8\% yang memiliki empat atau lebih perempuan anggota dewan. Perusahaan-perusahaan terbaik memiliki lima atau lebih anggota dewan perempuan diantaranya Tempo Scan Pacific Tbk, Bank CIMB Niaga Tbk, Bank Internasional Indonesia Tbk, Ciputra Surya Tbk, dan Mitra Adiperkasa Tbk. Jika dibandingkan dengan negara lainnya, nilai 11,6\% lebih rendah dari Eropa (17\%), Amerika Utara (16,1\%) dan Australia (13,8\%); namun lebih baik jika dibandingkan dengan rata- 
rata negara berkembang lainnya sebesar $7,2 \%$. Posisi Indonesia juga memimpin negara Asia lainnya, seperti Jepang (1,1\%), Hongkong (10,3\%), Malaysia $(7,3 \%)$ dan Singapura (7,3\%).

Penelitian Carter et al. (2007), keberagaman gender ditemukan tidak memiliki pengaruh terhadap kinerja keuangan perusahaan. Hal ini berdasarkan analisis regresi hasil perhitungan kinerja keuangan dengan menggunakan Tobin'S Q dan Return on Assets (ROA). Menurut Darmadi (2011), proposi perempuan pada tingkat eksekutif memiliki hubungan negatif terhadap total aset. Disimpulkan bahwa proposi perempuan yang tinggi pada tingkat dewan perusahaan umumnya terjadi pada perusahaan kecil yang berorientasi perusahaan keluarga. Terdapat kemungkinan bahwa perempuan dapat memegang kursi dewan perusahaan dikarenakan ikatan keluarga atau sebagai pemegang saham kendali. Oleh karena itu perusahaan-perusahaan yang besar dianggap lebih sulit bagi perempuan untuk memperoleh kesempatan di kursi dewan perusahaan. Sampel penelitian Darmadi (2011) adalah 354 perusahaan yang terdaftar di Bursa Efek Indonesia (BEI) pada tahun 2007. Metode yang digunakan untuk menghitung kinerja keuangan perusahaan juga sama seperti yang dilakukan Carter et al. (2007) yaitu dengan menggunakan Tobin's Q dan ROA.

Selain pengaruh keberagaman gender dengan performa perusahaan, penulis juga menganalisis pengaruh keberagaman gender terhadap efisiensi investasi perusahaan. Baik manajer maupun pemilik perusahaan memilliki peran yang penting dalam melakukan pilihan investasi. Pada tingkat pasar modal yang sempurna, manajer harus mampu memilih investasi yang tepat untuk memaksimalkan nilai pasar perusahaan.

Salah satu hal yang memengaruhi efisiensi investasi perusahaan adalah masalah asimetri informasi antara manajemen dan pasar modal, serta asimetri informasi antara manajemen dan pemegang saham yang dapat memengaruhi keputusan investasi dari sebuah perusahaan. Hal ini dapat berujung pada inefisiensi investasi. Verdi (2006) dan Biddle et al. (2009) menyatakan bahwa inefisiensi investasi tersebut termasuk melewatkan kesempatan investasi dengan net present value positif (underinvestment) dan juga melaksanakan proyek dengan net present value negatif (overinvestment).

Faccio et al. (2016) menyatakan bahwa tingkat risiko yang diambil oleh pembuat keputusan dalam proses pengambilan keputusan dapat memengaruhi tingkat efisiensi investasi. Besar kecilnya risiko yang diambil oleh pembuat keputusan dapat dipengaruhi oleh diversifikasi/keberagaman, salah satunya dari sisi gender. Terkait hubungan antara efisiensi investasi dengan keberagaman gender, Faccio et al. (2016) berpendapat bahwa Chief Executive Officer (CEO) perempuan tidak mengalokasikan modalnya secara efisien karena CEO perempuan cenderung menghindari risiko tinggi daripada CEO laki-laki. Hal tersebut menyiratkan bahwa kebijakan tersebut dapat merusak nilai-nilai yang dipegang para pemegang saham, karena CEO perempuan memiliki kecenderungan untuk melewati peluang investasi menguntungkan yang memiliki risiko lebih tinggi.

Penelitian ini bertujuan untuk menganalisis pengaruh keberagaman gender yang tidak terbatas hanya pada CEO, namun juga pada dewan komisaris dan dewan direksi. Pertanyaan yang akan dijawab dalam penelitian ini adalah bagaimana pengaruh keberagaman gender pada dewan komisaris dan direksi terhadap kinerja keuangan perusahaan dan efisiensi investasi.

\section{PENGEMBANGAN HIPOTESIS}

Terdapat berbagai argumen yang berbeda tentang hubungan antara keberagaman gender dan keunggulan kompetitif perusahaan. Beberapa argumen mendukung semakin tingginya tingkat keberagaman maka semakin tinggi juga kemungkinan keuntungan yang akan diperoleh perusahaan 


\section{Jurnal Keuangan dan Perbankan | KEUANGAN}

Vol. 21, No.1, Januari 2017: 1- 13

karena berbagai alasan. Campbell \& Minguez-Vera (2008) yang berpendapat bahwa keberagaman gender yang lebih besar di antara anggota dewan menghasilkan pendapat yang lebih beragam dan pemikiran kritis yang beragam sehingga membuat pengambilan keputusan lebih memakan waktu dan kurang efektif.

Resource dependence theory dan human capital theory tidak secara khusus memprediksi hubungan antara keberagaman dewan dengan kinerja keuangan perusahaan, tetapi mereka meyakini bahwa ada kemungkinan hubungan positif antara kedua hal tersebut. Sedangkan teori keagenan berpendapat adanya kemungkinan bahwa direksi yang beragam memungkinkan adanya pengawasan yang lebih baik dari manajemen, tapi belum terdapat hubungan yang jelas bagaimana keberagaman itu dapat meningkatkan kinerja perusahaan. Social Psychological Theory juga menunjukkan bahwa direksi yang beragam mungkin tidak memiliki pengaruh terhadap keputusan yang diberikan oleh dewan perusahaan. Walaupun anggota yang lebih beragam pada anggota dewan memungkinkan munculnya ide-ide kreatif dan inovatif tapi pengambilan keputusan akan jauh lebih lambat.

Di sisi lain, efisiensi investasi memiliki implikasi penting bagi perusahaan, karena tingkat efisiensi pada proses alokasi modal adalah fondasi dasar pertumbuhan ekonomi (Beck et al., 2000 dan John et al., 2008). Dalam pasar modal yang sempurna, manajer harus memilih investasi guna memaksimalkan nilai pasar perusahaan. Ekuivalen dengan pernyataan tersebut, manajer harus melakukan semua proyek dengan harapan bahwa net present value proyek tersebut memiliki nilai positif (Fama \& Miller, 1972). Dalam kerangka ini, baik preferensi manajer atau orang-orang dari pemilik perusahaan memainkan peran dalam pilihanpilihan investasi.

Sehubungan dengan pengambilan keputusan dalam proses investasi, terdapat bukti yang menyatakan bahwa keberagaman gender memiliki penga- ruh terhadap keputusan perusahaan. Hal tersebut berdasarkan pendapat Adams \& Ferreira (2009) yang memberikan bukti bahwa tingkat perputaran CEO berkorelasi lebih kuat dengan kinerja perusahaan yang buruk ketika dewan direksi memiliki gender yang lebih beragam. Ahern \& Dittmar (2012) menyatakan bahwa pengenalan terhadap kuota gender pada anggota dewan perusahaan menyebabkan peningkatan dalam akuisisi dan penurunan kinerja pada perusahaan publik di Norwegia.

Hal lain yang memengaruhi hubungan antara gender dengan efisiensi investasi adalah kecenderungan perempuan untuk mengambil risiko yang lebih rendah dibandingkan dengan laki-laki. Johnson \& Powell (1994) berpendapat bahwa perempuan menampilkan kecenderungan lebih rendah untuk mengambil risiko dibandingkan laki-laki. Perbedaan pada risk aversion ini menyebabkan dua hipotesis. Pertama, perusahaan yang dijalankan oleh CEO wanita akan membuat pilihanpilihan keputusan perusahaan yang kurang berisiko dan menghasilkan outcome yang kurang stabil. Hal ini merupakan konsekuensi langsung atas penghindaran risiko yang lebih tinggi. Kedua, menghindari proyek-proyek berisiko dengan ekspektasi net present value positif yang akan mengurangi efisiensi proses alokasi modal. (Faccio et al., 2016). Namun, bukti-bukti tersebut masih sangat sedikit untuk menyimpulkan bahwa perbedaanperbedaan ini mencakup pengambil keputusan perusahaan. Hal ini dikarenakan masih sedikitnya perempuan yang menjadi manajer puncak di perusahaan publik. Meskipun telah terdapat bukti bahwa perempuan lebih menghindari risiko dibandingkan laki-laki, mengingat terdapat kombinasi spesifik dan keterampilan yang dibutuhkan untuk naik ke posisi manajemen tinggi, maka seharusnya tidak ada perbedaan antara pria dan wanita di antara para eksekutif puncak. Selanjutnya, tidak ada bukti langsung yang menyatakan bahwa pengambilan risiko yang dipengauhi oleh perbedaan gender dapat menyebabkan misalokasi modal (Faccio et al., 2016). 
Berdasarkan empat teori yang berkaitan dengan keberagaman gender (Resource Dependence Theory, Human Capital Theory, Agency Theory, dan Social Psychological Theory), disimpulkan bahwa tidak terdapat pengaruh positif ataupun negatif dari pengaruh keberagaman gender terhadap kinerja keuangan perusahaan. Walaupun Resource Dependence Theory dan Human Capital Theory meyakini bahwa ada kemungkinan hubungan positif antara kedua hal tersebut, tetapi kedua teori tersebut tidak secara khusus memprediksi adanya hubungan antara keberagaman dewan dengan kinerja keuangan perusahaan. Sedangkan Agency Theory juga berpendapat bahwa belum terdapat hubungan yang jelas kalau direksi yang beragam dapat meningkatkan kinerja perusahaan, walaupun dengan adanya direksi yang beragam memungkinkan adanya pengawasan yang lebih baik dari manajemen. Social Psychological Theory juga menunjukkan bahwa direksi yang beragam mungkin tidak memiliki pengaruh terhadap keputusan yang diberikan oleh dewan perusahaan. Walaupun anggota yang lebih beragam pada anggota dewan memungkinkan munculnya ide-ide kreatif dan inovatif tapi pengambilan keputusan akan jauh lebih lambat. Sehingga dari keempat teori tersebut disimpulkan bahwa hubungan keberagaman gender dengan kinerja perusahaan memiliki kemungkinan positif dan negatif dan masih belum memiliki bukti empiris yang kuat. Dengan demikian, hipotesis pertama penelitian ini adalah:
$\mathrm{H}_{1}$ : keberagaman gender pada komposisi dewan perusahaan dapat memengaruhi kinerja keuangan perusahaan.

Efisien atau tidaknya suatu investasi dipengaruhi oleh proses pengambilan keputusan manajemen dengan keberagaman gender sebagai salah satu faktor yang dapat memengaruhi proses tersebut. Dijelaskan juga bahwa perempuan umumnya cenderung menghindari risiko tinggi dalam proses pengambilan keputusan dibandingkan dengan laki-laki, sehingga dapat menimbulkan kecenderungan inefisiensi investasi. Dengan demikian, hipotesis kedua penelitian ini adalah sebagai berikut:

$\mathrm{H}_{2}$ : keberagaman gender pada komposisi dewan perusahaan memiliki pengaruh negatif terhadap efisiensi investasi.

\section{METODE}

Data dan sampel penelitian ini terdiri dari perusahaan yang terdaftar di Bursa Efek Indonesia (BEI) yang menerbitkan laporan tahunan (annual report) pada tahun 2012. Data tersebut dikumpulkan melalui perolehan data sekunder melalui data stream dan yang diperoleh dari website resmi BEI. Sampel yang diambil tidak memasukkan perusahaan-perusahaan pada industri keuangan karena memiliki karakter yang berbeda dibanding-

Tabel 1. Deskripsi Sampel

\begin{tabular}{lcc}
\hline \multicolumn{1}{c}{ Deskripsi } & $\begin{array}{c}\text { Jumlah } \\
\text { Perusahaan Model 1 }\end{array}$ & $\begin{array}{c}\text { Jumlah Perusahaan } \\
\text { Model 2a dan 2b }\end{array}$ \\
\hline Perusahaan yang tercatat di BEI tahun 2012 & 472 & 472 \\
$\begin{array}{l}\text { Perusahaan di Industri Keuangan } \\
\text { Perusahaan di Industri Property and Real Estate dan }\end{array}$ & $(74)$ & $(74)$ \\
$\begin{array}{l}\text { Building Construction } \\
\begin{array}{l}\text { Perusahaan yang tidak menerbitkan laporan tahunan di } \\
\text { website BEI }\end{array}\end{array}$ & $(54)$ & $(54)$ \\
Sampel yang mengandung data Outlier & & $(40)$ \\
Total sampel penelitian & $(22)$ & $(51)$ \\
\hline
\end{tabular}


kan dengan industri lainnya. Selain itu juga mengeluarkan data perusahaan tahun 2012 yang tidak lengkap. Proses penetapan sampel dapat dilihat pada Tabel 1.

Komponen variabel dependen terdiri dari dua faktor, yaitu kinerja keuangan perusahaan dan efisiensi investasi, sedangkan variabel independen ditentukan dari keberagaman gender yang terjadi pada anggota dewan, baik dewan komisaris, dewan direksi, dan direktur keuangan. Variabel kontrol yang digunakan berdasarkan tata kelola perusahaan yang terdiri dari ukuran perusahaan dan persentase komisaris independen pada anggota dewan. Operasionalisasi dan pengukuran variabel dapat dilihat pada Tabel 2.

\section{Model Pengujian Pengaruh Gender terhadap Kinerja Keuangan Perusahaan}

Model pengujian ini merupakan pengembangan dari model pengujian Carter et al. (2007), dengan menggunakan variabel dependen ROA sebagai proksi pengukuran kinerja keuangan perusahaan.
$\mathrm{ROA}_{\mathrm{i}}=\beta_{0}+\beta_{1} \mathrm{FBOC}_{\mathrm{i}}+\beta_{2} \mathrm{FBOD}_{\mathrm{i}}+\beta_{3} \mathrm{PFBC}_{\mathrm{i}}+$ $\beta_{4} \mathrm{PFBD}_{\mathrm{i}}+\beta_{5} \mathrm{SIZE}_{\mathrm{i}}+\beta_{6} \mathrm{PIC}_{\mathrm{i}}+\varepsilon_{\mathrm{i}} \ldots \ldots \ldots \ldots \ldots .$. (Model 1)

\section{Keterangan:}

$\mathrm{ROA}_{\mathrm{i}}=$ return on assets pada perusahaan $\mathrm{i}$ pada akhir periode;

Tabel 2. Operasionalisasi dan Pengukuran Variabel

\begin{tabular}{|c|c|c|}
\hline Variabel & Proksi & Pengukuran \\
\hline \multicolumn{3}{|l|}{ Variabel Dependen } \\
\hline $\begin{array}{l}\text { Kinerja keuangan } \\
\text { perusahaan }\end{array}$ & $\begin{array}{l}\text { Return On Asset } \\
\text { (ROA) }\end{array}$ & ROA $=\frac{\text { Laba Bersih }}{\text { Total Aset }} \times 100 \%$ \\
\hline Efisiensi investasi & $\begin{array}{l}\text { Leverage (Debt to } \\
\text { Asset Ratio) }\end{array}$ & DAR $=\frac{\text { Total Utang }}{\text { Total Aktiva }} \times 100 \%$ \\
\hline \multicolumn{3}{|l|}{ Variabel Independen } \\
\hline \multicolumn{3}{|l|}{ Variabel Utama } \\
\hline Dewan Komisaris & Dewan Komisaris & Variabel dummy: 1 jika perempuan sebagai komisaris \\
\hline Perempuan (FBOC) & Perempuan & $\begin{array}{l}\text { utama dan } 0 \text { untuk laki-laki sebagai komisaris utama } \\
\text { pada perusahaan i di akhir periode penelitian. }\end{array}$ \\
\hline Dewan Direksi & Dewan Direksi & Variabel dummy: 1 jika perempuan sebagai direktur \\
\hline Perempuan (FBOD) & Perempuan & utama dan 0 untuk laki-laki sebagai direktur utama \\
\hline Proporsi Dewan & Proporsi Dewan & Proporsi wanita pada Dewan \\
\hline $\begin{array}{l}\text { Komisaris Perempuan } \\
\text { (PFBC) }\end{array}$ & $\begin{array}{l}\text { Komisaris } \\
\text { Perempuan }\end{array}$ & $\begin{array}{l}\text { dibandingkan dengan jumlah Dewan Komisaris } \\
\text { secara keseluruhan. }\end{array}$ \\
\hline Proporsi Dewan Direksi & Proporsi Dewan & Proporsi wanita pada Dewan Direksi dibandingkan \\
\hline Perempuan (PFBD) & Direksi Perempuan & dengan jumlah Dewan Direksi secara keseluruhan. \\
\hline \multicolumn{3}{|l|}{ Variabel Kontrol } \\
\hline $\begin{array}{l}\text { Ukuran } \quad \text { Perusahaan } \\
\text { (SIZE) }\end{array}$ & $\begin{array}{l}\text { Logaritma natural } \\
\text { dari total aset }\end{array}$ & $\mathrm{SIZE}=\ln ($ Total Aset $)$ \\
\hline Proporsi Dewan & Proporsi Dewan & Jumlah komisaris independen dibandingkan dengan \\
\hline Komisaris Independen & Komisaris & jumlah seluruh anggota dewan komisaris. \\
\hline (PIC) & Independen & \\
\hline
\end{tabular}




\section{Semakin Beragam Semakin Baik? Isu Keberagaman Gender, Keuangan, dan Investasi Perusahaan}

Zhafarina Isti Ramadhani \& Desi Adhariani

$\mathrm{FBOC}_{\mathrm{i}}=$ variabel dummy yang bernilai 1 jika perempuan sebagai komisaris utama dan 0 untuk laki-laki sebagai komisaris utama pada perusahaan i di akhir periode penelitian.

$\mathrm{FBOD}_{\mathrm{i}}=$ variabel dummy yang bernilai 1 jika perempuan sebagai direktur utama dan 0 untuk laki-laki sebagai direktur utama pada perusahaan i di akhir periode penelitian.

$\mathrm{PFBC}_{\mathrm{i}}=$ proposi dewan komisaris perempuan pada perusahaan i pada akhir periode penelitian.

$\mathrm{PFBD}_{\mathrm{i}}=$ proposi dewan direksi perempuan pada perusahaan i pada akhir periode penelitian.

SIZE $_{\mathrm{i}}=$ ukuran perusahaan yang diukur dari natural logaritma atas total aser perusahaan i pada akhir periode penelitian.

$\mathrm{PIC}_{\mathrm{i}}=$ proposi jumlah komisaris independen atas jumlah total dewan komisaris perusahaan i pada akhir periode penelitian.

$\varepsilon_{\mathrm{i}} \quad=$ error term, yaitu tingkat kesalahan penduga dalam penelitian

\section{Model Pengujian Pengaruh Gender terhadap Efisiensi Investasi}

Model pengujian pengaruh gender terhadap efisiensi investasi ini merupakan pengembangan dari model pengujian Faccio et al., 2016), dengan menggunakan variabel dependen ROA dan leverage sebagi proksi pengukuran efisiensi investasi perusahaan. ROA merupakan volatilitas atas earning yang didapatkan atas penggunaan aset perusahaan. Volatilitas tersebut merupakan standar pengukuran untuk mengukur tingkat risiko atas keputusan suatu investasi. Sedangkan leverage digunakan untuk mengukur indikasi tingkat risiko keuangan yang diambil oleh dewan komisaris dan dewan direksi perempuan jika dibandingkan dengan laki-laki.

$$
\begin{aligned}
& \text { ROA }_{i}= \beta_{0}+\beta_{1} \text { FBOC }_{i}+\beta_{2} \text { FBOD }_{i}+\beta_{3} \text { PFBC }_{i} \\
&+\beta_{4} \text { PFBD }_{i}+\beta_{5} \text { SIZE }_{i}+\beta_{6} \text { PIC }_{i}+\beta_{7} \\
& \text { LEVERAGE }_{i}+\varepsilon_{i} \ldots \ldots \ldots \ldots \ldots \ldots \\
& \text { LEVERAGE }_{i}= \beta_{0}+\beta_{1} \text { FBOC }_{i}+\beta_{2} \text { FBOD }_{i}+\beta_{3} \text { PFBC }_{i} \\
&+\beta_{4} \text { PFBD }_{i}+\beta_{5} \text { SIZE }_{i}+\beta_{6} \text { PIC }_{i}+ \\
& \varepsilon_{i} \\
&\text { (Model } b)
\end{aligned}
$$

Keterangan:

$\mathrm{ROA}_{\mathrm{i}}=$ return on assets pada perusahaan $\mathrm{i}$ pada akhir periode

LEVERAGE $_{\mathrm{i}}=$ rasio financial debt dibagi dengan jumlah total aset. Financial debt merupakan jumlah utang jangka panjang (tidak termasuk kewajiban tidak lancar lainnya) ditambah utang jangka pendek perusahaan i pada akhir periode penelitian.

Keterangan untuk variabel-variabel yang lain sama dengan model untuk menguji pengaruh gender terhadap kinerja keuangan.

\section{HASIL}

\section{Hasil Analisis Statitistik Deskripsi}

Berdasarkan Tabel 3 dapat terlihat bahwa rata-rata ROA perusahaan pada sampel untuk model 1 sebesar 0,0484 yang berarti bahwa rata-rata income yang diperoleh perusahaan atas penggunaan aset yang dimiliki adalah sebesar 4,84\% dengan standar deviasi atas ROA sebesar 7,1\%. Sehingga persebaran ROA ini rentangnya terletak antara nilai minimum sebesar -1,723 dan nilai maksimum 0,594. Sedangkan pada model 2 dan 3, rata-rata nilai ROA pada 253 sampel sebesar 0,0455 . Nilai tersebut berbeda tipis dengan rata-rata nilai ROA pada model 1, dengan rata-rata income yang diperoleh perusahaan atas penggunaan asetnya sebesar $4,55 \%$ yang berasal dari rentang nilai minimum -0,1857 
dan nilai maksimum 0,2444 sehingga persebaran standar deviasinya sebesar $6,23 \%$, lebih rendah dari standar deviasi model 1.

Pada model 1, nilai rata-rata variabel FBOD sebesar 0,0638 dengan persebaran standar deviasi sebesar 0,2449 . Hal ini menunjukkan bahwa hanya terdapat 6,38\% jumlah perempuan sebagai direktur utama dan sisanya sebesar $93,62 \%$ merupakan lakilaki. Variabel FBOC, nilai rata-rata yang diperoleh sebesar 0,0851 dengan standar deviasi sebesar 0,2795 . Jumlah komisaris utama perempuan hanya sebesar $8,51 \%$ dari total keseluruhan sampel dengan proporsi laki-laki sebesar 91,49\%, sehingga dapat terlihat bahwa posisi komisaris utama dan direktur utama masih lebih didominasi oleh lakilaki. Rata-rata proposi anggota dewan komisaris perempuan atas total anggota dewan komisaris keseluruhan sebesar 10,1442. Nilai tersebut lebih rendah jika dibandingkan dengan proposi anggota dewan direksi perempuan sebesar 12,5867 dengan masing-masing standar deviasi sebesar 18,3919 dan 18,1653. Hal ini menunjukkan bahwa pada model
1 jumlah dewan direksi perempuan pada perusahaan terdaftar di BEI tahun 2012 lebih banyak jumlahnya jika dibandingkan dengan jumlah dewan komisaris perempuan dengan rentang nilai minimum 0 dan nilai maksimum 100, sehingga terdapat perusahaan yang memiliki perempuan sebagai dewan komisaris dan dewan direksi sebanyak $100 \%$ dan ada yang sama sekali tidak memiliki anggota dewan komisaris dan direksi perempuan.

Berbeda dengan model 1, pada model 2a dan $2 b$ variabel FBOD memiliki rata-ratanya sebesar 0,0593 yang menunjukkan hanya 5,93\% jumlah perempuan sebagai direktur utama dan sisanya sebesar 94,07\% merupakan laki-laki. Sedangkan untuk variabel FBOC, nilai rata-rata yang diperoleh sebesar 0,0870 berarti jumlah komisaris utama perempuan pada model ini hanya sebesar $8,7 \%$ dari total keseluruhan sampel dengan poporsi laki-laki sebesar 91,3\%. Sehingga dapat terlihat bahwa posisi komisaris utama dan direktur utama pada model ini sama seperti model 1 yang lebih dido-

Tabel 3. Statistik Deskriptif Variabel Penelitian Model 1

\begin{tabular}{lcrrrr}
\hline \multicolumn{1}{c}{ Variabel } & Jumlah Sampel & \multicolumn{1}{c}{ Mean } & \multicolumn{1}{c}{ Std.Dev. } & \multicolumn{1}{c}{ Min } & \multicolumn{1}{c}{ Max } \\
\hline ROA & 282 & 0,0484 & 0,0710 & $-1,1915$ & 0,2897 \\
FBOC & 282 & 0,0851 & 0,2795 & 0 & 1 \\
FBOD & 282 & 0,0638 & 0,2449 & 0 & 1 \\
PFBC & 282 & 10,1442 & 18,3919 & 0 & 100 \\
PFBD & 282 & 12,5867 & 18,1653 & 0 & 100 \\
SIZE & 282 & 14,2470 & 1,7403 & 9,2670 & 19,0210 \\
PIC & 282 & 0,3814 & 0,1162 & 0 & 0,75 \\
\hline
\end{tabular}

Tabel 4. Statistik Deskriptif Variabel Penelitian Model 2a dan 2b

\begin{tabular}{lcrrrr}
\hline \multicolumn{1}{c}{ Variabel } & Jumlah Sampel & \multicolumn{1}{c}{ Mean } & \multicolumn{1}{c}{ Std.Dev. } & \multicolumn{1}{c}{ Min } & \multicolumn{1}{c}{ Max } \\
\hline ROA & 253 & 0,0455 & 0,0632 & $-0,1857$ & 0,2444 \\
LEVERAGE & 253 & 0,5262 & 0,1984 & 0,0395 & 0,9859 \\
FBOC & 253 & 0,0870 & 0,2823 & 0 & 1 \\
FBOD & 253 & 0,0593 & 0,2366 & 0 & 1 \\
PFBC & 253 & 10,4099 & 17,9942 & 0 & 75 \\
PFBD & 253 & 11,9165 & 16,5793 & 0 & 66,67 \\
SIZE & 253 & 14,2453 & 1,6855 & 9,7304 & 18,5284 \\
PIC & 253 & 0,3811 & 0,1162 & 0 & 0,75 \\
\hline
\end{tabular}


minasi oleh laki-laki. Pada rata-rata proposi anggota dewan komisaris perempuan atas total anggota dewan komisaris keseluruhan sebesar 10,4099 dengan nilai minimum 0 dan maksimum 75, sehingga dapat terlihat bahwa maksimum proposi perempuan pada dewan komisaris hanya sebesar 75\% dan ada yang tidak memiliki dewan komisaris perempuan sama sekali. Sedangkan proposi anggota dewan direksi perempuan, nilai rataratanya sebesar 11,9165 dengan nilai minimum 0 dan niai maksimum 66,67 yang menunjukkan bahwa maksimum proposi wanita pada dewan direksi sebesa 66,67\%. Dari penjelasan tersebut terlihat bahwa pada model 2 jumlah dewan direksi perempuan pada perusahaan terdaftar di BEI tahun 2012 lebih banyak jumlahnya jika dibandingkan dengan jumlah dewan komisaris perempuan, namun tidak ada perusahaan yang 100\% memiliki dewan komisaris atau dewan direksi perempuan secara keseluruhan.

\section{Analisis Hasil Pengujian Model}

Berdasarkan pengolahan data pada model 1 , model 2a, dan model $2 \mathrm{~b}$, hasil analisis regresi dapat ditunjukkan pada Tabel 4, 5, dan 6 .
Berdasarkan Tabel 4 terlihat bahwa tidak terdapat pengaruh FBOC dan FBOD terhadap ROA, sedangkan variabel PFBC dan PFBD yang merepresentasikan proporsi perempuan pada anggota dewan komisaris dan dewan direksi memiliki nilai signifikan sehingga dapat disimpulkan bahwa dari keempat variabel tersebut (FBOC, FBOD, PFBC, dan PFBD) yang mengukur tentang keberagaman gender pada anggota dewan komisaris dan dewan direksi tidak memiliki pengaruh yang signifikan terhadap kinerja keuangan yang diukur dengan ROA.

Pengukuran efisiensi investasi perusahaan pada penelitian ini menggunakan dua model, yaitu model 2a dan model 2b. Model 2a mengukur efisiensi investasi dari ROA untuk melihat earning yang didapatkan perusahaan atas penggunaan aset perusahaan yang efisien. Sedangkan model $2 \mathrm{~b}$ diukur menggunakan leverage untuk mengukur indikasi tingkat risiko keuangan yang diambil oleh dewan direksi dan dewan komisaris perempuan dalam mengambil keputusan investasi.

Berdasarkan Tabel 5 pada model 2a, dapat disimpulkan bahwa tidak terdapat pengaruh signifikan dari posisi perempuan pada komisaris

Tabel 4. Hasil Pengujian Model 1

\begin{tabular}{lcrrr}
\hline $\begin{array}{c}\text { ROA Variabel } \\
\text { Dependen }\end{array}$ & Prediksi & Coefficient & $\mathbf{t}$ & Sig P > (t) \\
\hline Konstanta & Berpengaruh & $-0,0429327$ & $-1,15$ & 0,251 \\
FBOC & Berpengaruh & $-0,0160183$ & $-0,89$ & 0,372 \\
FBOD & 0,0161781 & 0,84 & 0,402 \\
PFBC & Berpengaruh & 0,0003310 & 1,21 & 0,227 \\
PFBD & Berpengaruh & $-0,0002483$ & $-0,94$ & 0,349 \\
SIZE & Positif & 0,0087087 & 3,58 & $0,000^{* *}$ \\
PIC & Positif & $-0,0855499$ & $-2,36$ & $0,019^{*}$ \\
\hline Jumlah & & & 282 \\
Prob $>$ F & & & $0,0035^{*}$ \\
R-square $\left(\mathrm{R}^{2}\right)$ & & & 0,0678 \\
Adj.R-square $\left(\mathrm{R}^{2}\right)$ & & & 0,0474 \\
\hline
\end{tabular}

Ket:**Tingkat signifikan $\alpha=1 \%$ (one-tailed); * Tingkat signifikan $\alpha=5 \%$ (one-tailed). 
utama maupun direktur utama dalam meningkatkan efisiensi investasi perusahaan. Begitu juga dengan variabel PFBD menunjukkan bahwa besar kecilnya proporsi perempuan pada dewan direksi tidak berpengaruh terhadap tingkat efisiensi investasi perusahaan. Sedangkan pada variabel PFBC, nilai signifikannya sebesar 0,090 . Nilai tersebut lebih besar dari $\alpha=0,05$ namun masih lebih rendah jika menggunakan $\alpha=0,10$. Hal ini berarti proporsi perempuan pada dewan komisaris masih memiliki sedikit pengaruh terhadap efisiensi investasi perusahaan.
Berdasarkan Tabel 6, nilai signifikan FBOC dan FBOD masing-masing sebesar 0,875 dan 0,382. Nilai tersebut lebih besar dari $\alpha=0,05$. Begitu juga variabel PFBC dan PFBD yang memiliki nilai signifikan 0,692 dan 0,311 lebih besar dari batas $\alpha=0,05$. Hal ini berarti tidak ada pengaruh gender terkait tingkat leverage suatu perusahaan dalam membuat keputusan alokasi investasi, sehingga jika dilihat secara keseluruhan, tidak ada pengaruh keberagaman gender pada komposisi dewan perusahaan terhadap efisiensi investasi, baik pengaruh positif maupun negatif, sehingga hipotesis 2 $\left(\mathrm{H}_{2}\right)$ ditolak.

Tabel 5. Hasil Pengujian Model 2a

\begin{tabular}{lcrrr}
\hline $\begin{array}{c}\text { ROA Variabel } \\
\text { Dependen }\end{array}$ & Prediksi & Coefficient & t & Sig P > (t) \\
\hline Konstanta & Negatif & 0,0417558 & 1,27 & 0,207 \\
FBOC & Negatif & $-0,0122826$ & $-0,81$ & 0,416 \\
FBOD & 0,0176458 & 1,05 & 0,295 \\
PFBC & Negatif & 0,0004037 & 1,70 & 0,090 \\
PFBD & Negatif & 0,0002122 & $-0,87$ & 0,385 \\
SIZE & Positif & 0,0072718 & 3,23 & $0,001^{* *}$ \\
PIC & Positif & $-0,0829220$ & $-2,60$ & $0,010^{* *}$ \\
LEVERAGE & Negatif & $-0,1327927$ & $-7,11$ & $0,000^{* *}$ \\
\hline Jumlah & & & & 253 \\
Prob $>$ F & & & $0,0000^{* *}$ \\
R-square $\left(R^{2}\right)$ & & & 0,2037 \\
Adj.R-square $\left(R^{2}\right)$ & & & 0,1810 \\
\hline
\end{tabular}

Ket:**Tingkat signifikan $\alpha=1 \%$ (one-tailed); * Tingkat signifikan $\alpha=5 \%$ (one-tailed).

Tabel 6. Hasil Pengujian Model 2b

\begin{tabular}{lcrcc}
\hline $\begin{array}{c}\text { ROA Variabel } \\
\text { Dependen }\end{array}$ & Prediksi & Coefficient & t & Sig P > (t) \\
\hline Konstanta & Negatif & 0,1539276 & 1,37 & 0,171 \\
FBOC & Negatif & $-0,0081008$ & $-0,16$ & 0,875 \\
FBOD & Negatif & 0,0001157 & $-0,88$ & 0,382 \\
PFBC & Negatif & 0,0008436 & 0,40 & 0,692 \\
PFBD & Positif & 0,0272806 & 1,02 & 0,311 \\
SIZE & Positif & $-0,0683260$ & $-0,63$ & $0,000^{* *}$ \\
PIC & & & 0,530 \\
\hline Jumlah & & & 253 \\
Prob $>$ F & & & $0,0299^{*}$ \\
R-square $\left(\mathrm{R}^{2}\right)$ & & & 0,0548 \\
Adj.R-square $\left(\mathrm{R}^{2}\right)$ & & & 0,0318 \\
\hline
\end{tabular}

Ket:**Tingkat signifikan $\alpha=1 \%$ (one-tailed); * Tingkat signifikan $\alpha=5 \%$ (one-tailed). 


\section{PEMBAHASAN}

\section{Pengaruh Keberagaman Gender pada Komposisi Dewan Perusahaan terhadap Kinerja Keuangan Perusahaan}

Hasil analisis menunjukkan bahwa keberagaman gender pada anggota dewan komisaris dan dewan direksi tidak memiliki pengaruh yang signifikan terhadap kinerja keuangan yang diukur dengan ROA. Hasil ini bertolak belakang dengan hipotesis 1 yang menyatakan bahwa keberagaman gender pada komposisi dewan perusahaan memiliki pengaruh terhadap kinerja keuangan. Hasil tersebut juga bertolak belakang dengan Resources Dependency Theory yang menyatakan bahwa keberagaman dewan komisaris dan direksi memiliki potensi untuk meningkatkan informasi yang unik untuk diberikan ke manajemen sehingga diharapkan dapat memberikan nilai tambah dalam membuat suatu keputusan untuk menghasilkan kinerja perusahaan yang lebih baik. Namun hasil ini konsisten dengan hasil penelitian Carter et al. (2007) yang menyatakan tidak terdapat hubungan antara keberagaman gender terhadap kinerja keuangan perusahaan, serta Agency Theory yang menyatakan bahwa masih belum ada hubungan yang pasti bahwa keberagaman anggota dewan direksi dan komisaris dapat meningkatkan kinerja keuangan perusahaan. Selain itu, jumlah dewan komisaris dan dewan direksi perempuan masih terlalu sedikit jika dibandingkan dengan jumlah dewan komisaris dan dewan direksi laki-laki. Hal ini dikarenakan posisi perempuan pada anggota dewan umumnya juga masih disebabkan karena faktor keluarga dan umumnya terjadi pada perusahaan kecil (Darmadi, 2011), sehingga sulit untuk mengukur apakah posisi perempuan pada anggota dewan tersebut hanya dikarenakan faktor keluarga saja atau memang karena kompetensinya yang baik sehingga dapat meningkatkan kinerja keuangan perusahaan.

\section{Pengaruh Keberagaman Gender pada Komposisi Dewan Perusahaan terhadap Efisiensi Investasi}

Berdasarkan hasil analisis menunjukkan bahwa tidak ada pengaruh keberagaman gender pada komposisi dewan perusahaan terhadap efisiensi investasi, baik pengaruh positif maupun negatif. Hasil ini bertolak belakang dengan penelitian Faccio et al. (2016) yang berpendapat bahwa CEO perempuan memiliki kecenderungan untuk melewati peluang investasi yang menguntungkan dengan risiko yang lebih tinggi sehingga menyebabkan efisiensi investasi perusahaan tidak efisien. Hal ini berarti masih terdapat faktorfaktor lain yang memengaruhi pengambilan keputusan investasi selain risk aversion pada dewan komisaris dan dewan direksi perempuan, salah satunya kemungkinan terjadinya moral hazard.

Moral hazard terjadi ketika manajer lebih mementingkan untuk memaksimalkan kesejahteraan personalnya dalam melakukan investasi tanpa mengedepankan kepentingan pemegang saham (Jensen \& Meckling, 1976) sehingga dapat menyebabkan pembuat keputusan tidak mengalokasikan investasinya secara efisien. Untuk menghindari moral hazard ini dapat dilakukan pengawasan yang lebih ketat terhadap dewan perusahaan, salah satunya dengan mekanisme pengawasan dari dewan komisaris dan dewan direksi independen, sehingga diharapkan keputusan yang diambil dalam proses alokasi aset perusahaan terhindar dari kepentingan pribadi dan menghasilkan alokasi investasi perusahaan yang efisien.

\section{SIMPULAN DAN SARAN}

\section{Simpulan}

Penelitian ini membahas tentang pengaruh keberagaman gender pada dewan komisaris dan dewan direksi terhadap kinerja keuangan dan efi- 
siensi investasi pada perusahaan yang terdaftar di BEI. Keberagaman gender memiliki pengaruh terhadap kinerja keuangan perusahaan, baik pengaruh positif maupun negatif. Hipotesis ini didasarkan pada Resource Dependency Theory dan Human Capital Theory. Namun, berdasarkan hasil pengujian ditemukan bahwa keberagaman gender pada komposisi dewan perusahaan tidak memengaruhi kinerja keuangan perusahaan. Salah satu kemungkinan penyebabnya adalah jumlah dewan komisaris dan dewan direksi perempuan yang jauh lebih sedikit jika dibandingkan dengan dewan komisaris dan dewan direksi laki-laki, sehingga ada kemungkinan pengaruh faktor keluarga dalam menetapkan perempuan sebagai anggota dewan, yang dapat menyebabkan kompetensinya dianggap tidak mampu dalam meningkatkan kinerja keuangan perusahaan

Keberagaman gender pada komposisi dewan perusahaan memiliki pengaruh negatif terhadap efisiensi investasi. Hal ini dikarenakan perempuan cenderung menghindari risiko tinggi dalam proses pengambilan keputusan dibandingkan laki-laki. Sehingga perempuan cenderung melewatkan kesempatan yang menguntungkan dalam suatu investasi yang dapat merugikan perusahaan (Faccio et al., 2016). Namun, berdasarkan hasil penelitian ditemukan bahwa variabel independen yang berkaitan dengan keberagaman gender tidak memiliki pengaruh yang signifikan terhadap efisiensi investasi. Sehingga hipotesis bahwa keberagaman gender dapat berpengaruh negatif terhadap efisiensi investasi ditolak. Variabel yang memengaruhi efisiensi investasi justru berasal dari variabel kontrol yaitu ukuran perusahaan, proporsi komisaris independen, dan tingkat utang.

\section{Saran}

Penelitian selanjutnya diharapkan dapat menggunakan metode data panel untuk penelitian lebih dari satu tahun, sehingga dapat melihat perbandingan dari tahun yang satu dan yang lain-
nya.Penelitian selanjutnya diharapkan dapat menggunakan proksi kinerja keuangan dan efisiensi investasi lainnya seperti ROE, Tobin's $Q$, analisis keberlangsungan perusahaan, dan rasio lainnya. Sehubungan dengan persentase wanita di dewan yang masih sedikit, maka penelitian selanjutnya dapat mempertimbangkan penggunaan metode studi kasus atau kualitatif untuk meneliti peran wanita di dewan dan penagruh keberagam gender secara lebih mendalam.

Walaupun hasil penelitian ini belum bisa memberikan dukungan ilmiah tentang pengaruh keberagaman gender namun dengan mendasarkan pada hasil-hasil penelitian sebelumnya yang menemukan sebaliknya, dan berdasarkan best practices perusahaan-perusahaan di dunia yang telah memetik manfaat dari keberagaman gender pada dewan maka perusahaan-perusahaan di Indonesia bisa mempertimbangkan hal tersebut dengan memperbesar persentase wanita yang duduk di dewan komisaris dan direksi selama mereka memang memiliki kemampuan yang dibutuhkan pada posisi tersebut. Khusus untuk dewan direksi yang bisa diisi staf internal dari jalur karir maka perusahaan perlu meningkatkan kapabilitas para karyawan wanita yang memiliki kemampuan untuk mencapai posisi direktur, misalnya dengan mengadakan pelatihan rutin atau menggunakan sistem mentorship.

\section{DAFTAR PUSTAKA}

Adams, R.B. \& Ferreira, D. 2009. Women in the Boardroom and Their Impact on Governance and Performance. Journal of Financial Economics, 94(2): 291309.

Ahern, K.R., \& Dittmar, A.K. 2012. The Changing of the Boards: The Impact on Firm Valuation of Mandated Female Board Representation. The Quarterly Journal of Economics, 127(1): 137-197.

Bantel, K. A., \& Jackson, S. E. 1989. Top Management and Innovations in Banking: Does the Composition of the Top Team Make a Difference? Strategic Management Sournal, 10(1): 107-124. 


\section{Semakin Beragam Semakin Baik? Isu Keberagaman Gender, Keuangan, dan Investasi Perusahaan}

Zhafarina Isti Ramadhani \& Desi Adhariani

Beck, T., Levine, R., \& Loayza, N. 2000. Finance and the Sources of Growth. Journal of Financial Economics, 58(1): 261-300.

Biddle, G.C., Hilary, G., \& Verdi, R.S. 2009. How Does Financial Reporting Quality Relate to Investment Efficiency? Journal of Accounting and Economics, 48(2): 112-131.

Campbell, K., \& Minguez-Vera, A. 2008. Gender Diversity in the Boardroom and Firm Financial Performance. Journal of Bussiness Ethics, 83(3): 435- 451.

Carter, D.A., D'Souza, F., Simkins, B.J., \& Simpson, W.G. 2007. The Diversity of Corporate Board Committees and Financial Performance. http:/ / ssrn.com/ abstract $=1106698$. Diakses tanggal 17 Nopember 2016.

Centre for Governance, Institutions and Organisations (CGIO). 2012. Indonesia Boardroom Diversity Report 2012: Female Footprints in IDX-listed Companies. NUS Business School. Singapore.

Coffey, B.S., \& Wang, J. 1998. Board Diversity and Managerial Control as Predictors of Corporate Social Performance. Journal of Business Ethics, 17(14): 15951603.

Darmadi, S. 2011. Board Diversity and Firm Performance: The Indonesian Evidence. Corporate Ownership and Control, 1(9): 524-539.

Faccio, M., Marchica, M. T., \& Mura, R. 2016. CEO Gender, Corporate Risk-taking, and the Efficiency of Capital Allocation. Journal of Corporate Finance, 39: 193-209.

Fama, E.F. \& Miller, M.H. 1972. The Theory of Finance. Holt Rinehart \& Winston.

Goodstein, J., Gautam, K., \& Boeker, W. 1994. The Effects of Board Size and Diversity on Strategic Change. Strategic Management Journal, 15(3):241250.
Jackson, S.E., \& Alvarez, E.B. 1992. Working through Diversity as A Strategic Imperative. New York: The Guilford Press.

Jensen, M.C., \& Meckling, W.H. 1976. Theory of The Firm: Managerial Behavior, Agency Costs and Ownership Structure. Journal of Financial Economics, 3(4): 305-360.

John, K., Litov, L., \& Yeung, B. 2008. Corporate Governance and Risk taking. The Journal of Finance, 63(4): 1679-1728.

Johnson, J.E., \& Powell, P.L. 1994. Decision Making, Risk and Gender: Are Managers Different? British Journal of Management, 5(2): 123-138.

Kim, K., Nofsinger, J., \& Mohr, D. 2009. Corporate Governance. $3^{\text {rd }}$ Edition. London: Prentice Hall.

Rose, C. 2007. Does Female Board Representation Influence Firm Performance? The Danish Evidence. Corporate Governance: An International Review, 15(2): 404-413.

Sessa, V. I., \& Jackson, S.E. 1995. Diversity in Decisionmaking Teams: All Differences are Not Created Equal. In: Diversity in Organizations: New Perspectives for a Changing Workplace. Edited by: Chemers, M.M., Oskamp, S., \& Costanzo, M.A. Thousands Oak, CA: Sage.

Verdi, R.S. 2006. Financial Reporting Quality and Investment Efficiency. https://papers.ssrn.com/sol3/ papers2.cfm?abstract_id=930922. Diakses tanggal 23 Oktober 2016.

Wiersema, M.F. \& Bantel, K.A. 1992. Top Management Team Demography and Corporate Strategic Change. Academy of Management Journal, 35(1): 91121.

Zhuang, J., Edwards, D., Webb, D., \& Capulong, M.V. 2000. Corporate Governance and Finance in East Asia. Manila: Asian Development Bank. 